\title{
MARKETING MIX FACTORS THAT INFLUENCE THE DESIRE TO PURCHASE FRUIT BEVERAGES IN THE CITY OF BOGOR
}

\author{
Iffatul Ulfah")1, Ujang Sumarwan ${ }^{* *}$, and Dodik Ridho Nurrochmat ${ }^{* * * *}$ \\ *) School of Business, Bogor Agricultural University \\ Jl. Raya Pajajaran, Bogor 16151 \\ **) Department of Family and Consumer Sciences, Faculty of Human Ecologi, Bogor Agricultural University \\ Academic Ring Road, Campus IPB Dramaga, Bogor 16680 \\ ${ }^{* * *}$ Department of Forest Management, Faculty of Forestry, Bogor Agricultural University \\ Academic Ring Road, Campus IPB Dramaga PO Box 168, Bogor 16680
}

\begin{abstract}
The objectives of this research were 1) to analyze marketing mix factors that influence the desire to purchase fruit beverages, 2) to formulate the marketing strategies of fruit beverages at restaurant based on fruit beverages in the city of Bogor. This research was conducted by using descriptive methods through survey approach. Data was collected in questionnaires, using non probability sample approach with convenience sampling technique. Variables measured were $7 P$ 's marketing mix factors, namely product, place, price, promotion, physical evidence, process and people. The analysis that were used were descriptive analysis and discriminant analysis. The result of this research shows that price and physical evidence were two factors that discriminate consumer behaviour. This means that the purchase intention (desire) between consumers who buy and consumers who do not buy fruit beverages were affected by price and physical evidence factors. The discriminant function that discriminate consumers purchase intention is $D=$ $-3,339+0,619$ Physical $+0,899$ Price and cut-off value -0,18624. This means that if discriminant value $(D)$ is higher than -0,18624, the consumer belongs to the group of consumer who will buy the fruit beverages and vice versa.
\end{abstract}

Keywords: consumer behaviour, purchase intention, marketing mix, discriminant analysis

\begin{abstract}
ABSTRAK
Penelitian ini bertujuan 1) menganalisis faktor bauran pemasaran yang memengaruhi keinginan membeli minuman es buah, 2) merumuskan strategi pemasaran minuman es buah pada restoran berbasis minuman es buah di Kota Bogor. Penelitian dilakukan menggunakan metode deskriptif dengan pendekatan survei. Data dikumpulkan melalui penyebaran kuisioner terhadap konsumen minuman es buah, menggunakan pendekatan non probability sample dengan teknik convenienve sampling. Variabel yang diukur adalah unsur-unsur bauran pemasaran 7P, yaitu product, place, price, promotion, physical evidence, process dan people. Analisis yang digunakan adalah analisis deskriptif dan analisis diskriminan. Hasil penelitian memperlihatkan bahwa unsur price (harga) dan physical evidence (lingkungan fisik) merupakan faktor bauran pemasaran yang membedakan perilaku konsumen. Hal ini diartikan bahwa keinginan konsumen untuk membeli dan tidak membeli minuman es buah dipengaruhi oleh faktor harga dan lingkungan fisik. Adapun fungsi diskriminan yang membedakan keinginan membeli yaitu $D=-3,339+0,619$ Physical $+0,899$ Price, dengan nilai batas sebesar -0,18624. Hal ini dapat diartikan apabila nilai diskriminan (D) lebih besar dari nilai -0,18624 maka konsumen tersebut masuk ke dalam kelompok yang akan membeli minuman es buah dan sebaliknya.
\end{abstract}

Kata kunci: perilaku konsumen, keinginan membeli, bauran pemasaran, analisis diskriminan

\footnotetext{
${ }^{1}$ Corresponding author:

Email:i.ulfah@gmail.com
} 


\section{INTRODUCTION}

The increasing interest of people and tourists in culinary tourism has given a chance to entrepreneurs to open up a culinary business. In addition, the people's consumptive behavior and lifestyle tend to consume foods not just to meet the needs but to satisfy lifestyle. Nowadays culinary tourism in a city does not only provide typical products of that city, but also repackage the typical food products of the city or redesign the interior of the restaurants with a unique style to create a new trend.

Bogor City is one of the towns that have encouraged culinary tourism as one of its powerful tourism. This is stated by the Mayor of Bogor, who targets Bogor as one of the top tourism destinations in Indonesia, by encouraging Indonesian Hotel and Restaurant Association (PHRI) to become a tourism driving force that can compete with other tourism cities (Kompas. com, 2014). One of the culinary business types that are well developed in Bogor City is fruit beverages. Sop Duren Lodaya and Sop Duren Rancamaya are restaurant business that is based on fruit beverages originating from Bogor. In the research carried by Dudesy (2014), it was stated that Sop Duren Lodaya was a pioneer of sop durian in Bogor area, which was established in 2012. Nowadays Sop Duren Lodaya has developed its business to many towns in Java Island. In the same year, Sop Durian Rancamaya started to exist, competing with Sop Duren Lodaya in Bogor City. Unlike Sop Buah Pak Ewok, Rochani (2007) said that Sop Buah Pak Ewok originated in Bandung and then in 2005 it was developed in Bogor by a young entrepreneur from Bogor using a different concept until it became a franchise business and developed as far as Sumatera. This also applies to Es Teler 77 restaurant, which is a franchise business that has developed not only in the country, but also abroad (Wikipedia, 2015).

On the other hand, according to the Ministry of Agriculture in Ria (2014), the level of fruit and vegetable consumption rate of Indonesian people is still low, that is only $40 \mathrm{~kg}$ per capita per year. This figure is still below the Food Agriculture Organization (FAO) recommendation, which is $65 \mathrm{~kg}$ per capita per year. From the viewpoint of nutrition, fruit and vegetables are closely related to vitamin sources, mineral sources, both micro and macro, and fiber sources. Sujono in Nainggolan and Adimunca (2005) said that urban people, some of whom are mobile and busy, tend to consume fast-food meals. This behavior causes a transition of eating pattern from that with high carbohydrates, high fiber, and low fat to eating pattern with low carbohydrates and fiber, high fat and protein. This causes high rate of diseases such as coronary heart disease, colon cancer, and other degenerative diseases in Indonesia. Some researches that have been carried out show that fruits support the body metabolism, which, if it is not fulfilled, will cause a serious disease (Santoso, 2011; Ginting, 2011; Pardede, 2013; GarciaAlonso et al. 2004; Piironen et al. 2003; and Terry et al. 2001). With reference to that, it is necessary to provide an alternative that can interest community to consume fruits. Fruit ice is another alternative that can attract people to consume fruits. This is one of the strengths of the fruit beverage-based restaurants.

In order to develop entrepreneurship potential and to face challenges from fruit alternatives, it is important to carry out a study that deals with consumer's perception about fruit beverages with marketing mix elements and their influences on the consumer's desire to buy fruit beverages. Consumers often decide buying a product based on their perception towards the product. According to Mowen and Minor (1999) perception is a stage where consumers get exposure, attention and comprehension in an information process. According to Sumarwan (2011) how a consumer sees reality beyond himself or his surrounding world is what is called as consumer's perception. Understanding consumer's perception is important for a marketer and producer.

In the decision-making model, Schiffman and Kanuk (2000) say that the consumer's external factor also plays a role to influence the consumer in making decisions, one of which is marketing mix elements. The meaning of marketing mix according to Kotler (2003) is a set of constituents used by a company continuously to reach its marketing goals in the target markets. The concept of marketing mix consists of four P elements, namely product, price, place and promotion. These four marketing mix elements are aimed to market products, seen from the producer's point of view. As for service marketing such as in a restaurant, Booms and Bitner in Indrajaya (2006) suggest to add three other P elements in the marketing mix, namely people (participants), physical evidence and process. Some researchers on marketing mix related to its implications on the buyers, sale improvement and marketing strategies have been carried out previously (Senjaya, 2014; Aritonang, 2014; Marwa, 2014; Susanti, 2013, Widowati, 2010; Rachmawati, 2011; Lin, 2011). 
The objective of this research is to analyze marketing mix factors that can influence the desire to buy fruit beverages and the marketing strategies based on the marketing mix elements.

The scope of the research is limited to several things, namely: 1) fruit-beverage-based restaurants are those that use fruit ice as its strength/superiority to other restaurants; 2) fruit beverages are those that use fruits as their main ingredients that can be combined with various fruits and other supplements such as milk, syrup, or other food ingredients. Fruit ice drinks do not include fruit juice that only serves its extract; 3) fruit ice consumers are limited to the people in Bogor City and tourists that come to Bogor City.

\section{METHOD}

The research on the fruit ice consumer's behavior was carried out in Bogor City for two months, from July to August 2015. The research location was chosen purposively in fruit-beverage-based restaurants in Bogor City and other strategic locations, such as malls, universities and housing complex in Bogor City. The research was carried out using a descriptive method a descriptive method. Data collection was carried out using a direct interview and survey with questionnaire instrument.
Sample taking was carried out randomly or nonprobability sample, with a convenience sampling method. The number of respondents was 100 people from Bogor City population, calculated using Slovin formula. The respondents chosen were the fruit ice consumers in fruit-beverage-based restaurants and some other strategic locations such as malls and campuses in Bogor.

In this research marketing mix elements (product, price, place, promotion, physical evidence, people and process) become independent variables, while the consumer behavior is the dependent variable. Questions are given in the form of Likert scale with 1-5 intervals. In the validity and reliability tests presented completely in Table 1, all the indicators of each variable has an $r$ calculation $>r$ tabel. On the other hand the alpha $(\alpha)$ value is bigger than the determined one $(0,7)$, so that it can be concluded that the questionnaire is valid and reliable as a research measurement.

The analysis used is a descriptive analysis and to find out the purchasing behavior discriminant analysis is used. Processing and analyzing data use a Microsoft Excel program and SPSS 16. The conceptual analysis framework of the research is presented in Figure 1.

Table 1. Results of validity and reliability tests of marketing mix elements

\begin{tabular}{llcc}
\hline \multicolumn{1}{c}{ Marketing mix } & \multicolumn{1}{c}{ Attribute } & r-calculation & Alpha $(\alpha)$ \\
\hline Product & Variety of fruit & 0,657 \\
& Benefits of fruit & 0,574 \\
& Fruit giving freshness & 0,532 \\
& Product performance & 0,562 \\
& Information on fruit content & 0,372 \\
& Fruit ice of healthy lifestyle & 0,362 \\
Price & Care for local fruit & 0,363 \\
Place & Choosing local fruit & 0,374 \\
Promotion & Price affects purchasing & 0,592 \\
Physical evidence & Location affects visit & 0,694 \\
Process & Choosing eating location in food court & 0,402 \\
& Promotion affects purchasing & 0,555 \\
People & Service affects visit & 0,623 \\
& Choosing one's own fruit ice combination & 0,528 \\
\hline
\end{tabular}




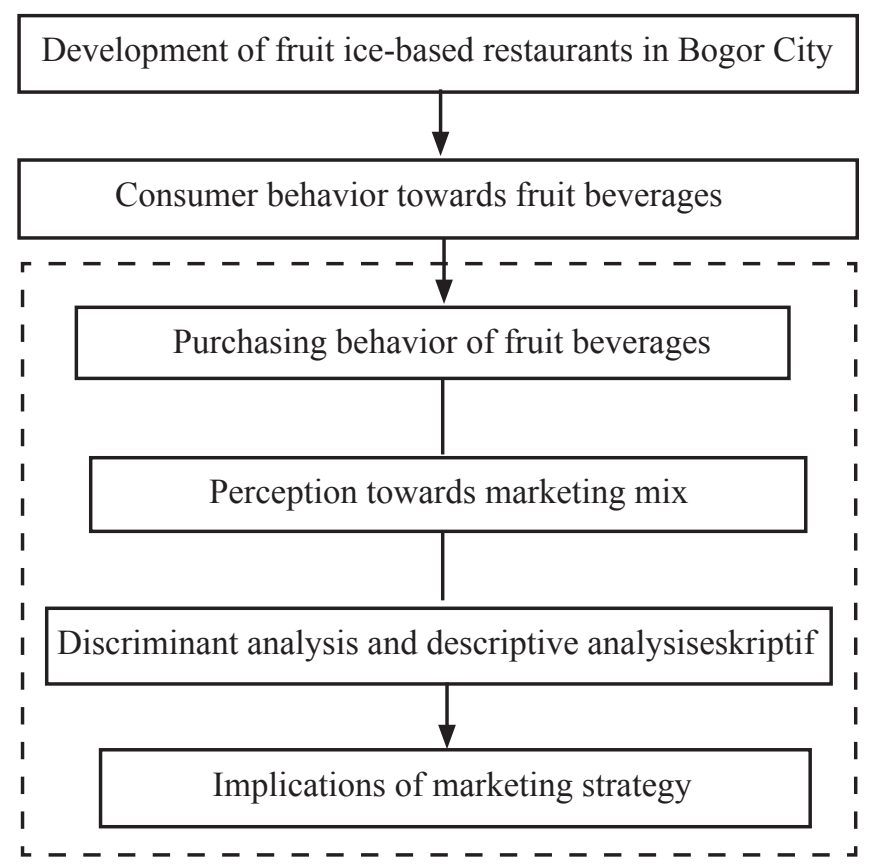

Figure 1. The conceptual framework

\section{RESULTS}

\section{Perception of Marketing Mix Elements}

Elements included in the 4P marketing mix, namely product, price, place, promotion and also $3 \mathrm{P}$ elements, namely physical evidence, process, people, have been raised in this research to be asked to respondents. Some additional questions related to development of fruitbeverage-based restaurants are also asked to consumers. Questions are proposed in the form of statements with Likert scale evaluation (5 scales), namely Agree very much (SS), Agree (S), Neutral (N), Not Agree (TS) and do not agree very much (STS); they are then summed to get the frequent percentage of each evaluation. The main objective of this discussion is to be able to develop business and marketing strategy of fruit-beveragebased restaurants in Bogor City based on the marketing mix principles.

In developing a business, products are important elements that need to be considered. However, one product has its own superiority compared to other products of the same type, so that being accepted well in the market is the most important thing to start a business. Fruit beverages have been developed well in Bogor City. Innovation and novelty of the beverage product is very important to present uniqueness of the product so that it can be accepted well by markets. From the research results presented in Table 2, it can be seen that majority respondents like fruit ice that has varied fruits. Respondents are also aware of getting the benefit of eating fruit ice. This certainly affects the continuity of purchasing. In addition, respondents are also interested in the contents of the fruit in the beverage they buy. This can be developed to attract consumers to buy fruit ice product. Furthermore, although it is not determined by purchasing, types of fruit that respondents like as the main ingredients of fruit ice are durians, mangos, avocadoes, and strawberries. Besides, respondents also say that product appearance also affects their likeness to fruit beverages.

Determining price on one product can be influenced by segmentation and positioning of the product itself. One product can be sold with higher prices from other similar products if it has an added-value which then will determine the target market. In this research, a question on the ideal price of fruit beverages expected by the consumers is also proposed. Respondents say that the ideal price of fruit beverages is between Rp10.000 and Rp15.000 (Table 3). The result is a price based on the consumers'expectation. However, determining the price of fruit beverages must also pay attention to production cost from upstream to downstream lines. In this case it is necessary to cooperate with fruit farmers around Bogor area, so that it is expected that it can reduce the production cost. A good cooperation with producers is expected to be able to reach a reasonable price suitable to the consumers' expectation. Respondents also say that the price of fruit beverages will affect the consumers' decision to buy them (Table 4).

In developing business of food or beverage-base, location is one of the most determining factors. A strategic and crowded location that is visited by consumers is on a business location that is close to some similar businesses can become its own market that makes it easy for consumers to look for whatever they need. In food and beverage business, food court or a centralized food place is a facility for consumers to get what they want. Table 5 shows information that restaurant locations affect the frequency of visits by the consumers of fruit beverages. In addition, consumers also like to go a place that is centralized when deciding to choose a place to eat, such as food court or a place with many choices of eating sites.

The next marketing mix element is promotion. By preparing an appropriate promotion, a business can develop well although the product offered does not have specialty from other similar products, or maybe its location is not strategic. Promotion can also give an added value of a product and give its own image so that 
the product becomes superior compared to other similar products. Based on the research results, a promotion form that is preferred by majority of respondents of fruit beverages is reduced price or discount (Table 7). The promotion media that is preferred by respondents of fruit beverages is social media (Table 8). According to Siswanto (2013), social media can give competitive superiority to Small-Middle Business (UKM). If it is used optimally, social media can create a brand image for the UKM and give satisfaction that can implicate to loyalties. Companies can choose any social media that is more effective to use for its own product promotion and business. However, most UKMs use more than one social media in marketing their products. The aim is their companies will get more consumers unlimited to specific community or social media users.

Table 2. Perception of Product element

\begin{tabular}{|c|c|c|c|c|c|}
\hline \multirow{2}{*}{ Statements } & \multicolumn{5}{|c|}{ Percentage $(\%) ; n=100$} \\
\hline & SS & $\mathrm{S}$ & $\mathrm{N}$ & TS & STS \\
\hline The more varied types of fruit in the fruit ice, the tastier & 29 & 36 & 20 & 13 & 2 \\
\hline Benefits of fruits in fruit beverages affect continuity of fruit ice purchasing & 23 & 44 & 22 & 10 & 1 \\
\hline Fruits, in fruit beverages, give freshness & 47 & 48 & 3 & 2 & - \\
\hline Fruit ice appearance affects one's likeness to fruit beverages & 36 & 50 & 9 & 5 & - \\
\hline $\begin{array}{l}\text { You will become interested in consuming fruit ice if there is information of nutrient } \\
\text { content of the fruits in fruit beverages }\end{array}$ & 28 & 47 & 14 & 11 & - \\
\hline Consuming fruit beverages shows healthy lifestyle & 10 & 36 & 37 & 15 & 2 \\
\hline You care for fruit ice if it is of local product & 19 & 37 & 31 & 13 & - \\
\hline In the fruit ice beverage, you tend to choose local fruits rather than imported ones & 21 & 20 & 43 & 15 & 1 \\
\hline
\end{tabular}

Table 3. Ideal price for fruit beverages

\begin{tabular}{lc}
\hline \multicolumn{1}{c}{ Ideal price of fruit beverages } & Percentage $(\mathrm{n}=100)$ \\
\hline$<\mathrm{Rp} 10.000$ & $14 \%$ \\
Rp10.000-Rp15.000 & $56 \%$ \\
Rp15.000-Rp20.000 & $21 \%$ \\
$>$ Rp20.000 & $9 \%$ \\
\hline
\end{tabular}

Table 4. Perception of price element

\begin{tabular}{|c|c|c|c|c|c|}
\hline \multirow{2}{*}{ Statements } & \multicolumn{5}{|c|}{ Percentage $(\%) ; n=100$} \\
\hline & $\mathrm{SS}$ & $\mathrm{S}$ & $\mathrm{N}$ & TS & STS \\
\hline Fruit ice beverage price affects your purchasing decision & 26 & 44 & 21 & 9 & - \\
\hline
\end{tabular}

Table 5. Perception of location element

\begin{tabular}{|c|c|c|c|c|c|}
\hline \multirow{2}{*}{ Statements } & \multicolumn{5}{|c|}{ Percentage $(\%) ; n=100$} \\
\hline & SS & $\mathrm{S}$ & $\mathrm{N}$ & TS & STS \\
\hline Restaurant locations affect the frequency of your visits & 27 & 54 & 16 & 3 & - \\
\hline $\begin{array}{l}\text { In determining eating sites, you prefer to go to a food court or a place which can pro- } \\
\text { vide many choices of eating sites }\end{array}$ & 18 & 41 & 30 & 10 & 1 \\
\hline
\end{tabular}

Table 6. Perception of promotion element

\begin{tabular}{|c|c|c|c|c|c|}
\hline \multirow{2}{*}{ Statements } & \multicolumn{5}{|c|}{ Percentage $(\%) ; n=100$} \\
\hline & SS & $\mathrm{S}$ & $\mathrm{N}$ & TS & STS \\
\hline Promotion affects you to buy fruit beverages. & 18 & 32 & 32 & 18 & - \\
\hline
\end{tabular}

Table 7. Promotion form preferred by fruit ice consumers

\begin{tabular}{lc}
\hline \multicolumn{1}{c}{ Attractive promotion form } & Percentage $(\mathrm{n}=100)$ \\
\hline Reduced price & $48 \%$ \\
Instant prize & $5 \%$ \\
Direct promotion & $3 \%$ \\
Purchasing promotion & $44 \%$ \\
\hline
\end{tabular}


Table 8 . Promotion media preferred by fruit ice consumers

\begin{tabular}{lc}
\hline \multicolumn{1}{c}{ Desired promotion } & Persentase $(\mathrm{n}=100)$ \\
\hline Newspapers & - \\
Pamphlets (flyer) & $19 \%$ \\
Social media & $40 \%$ \\
Direct promotion when purchasing & $40 \%$ \\
Others & $1 \%$ \\
\hline
\end{tabular}

Physical evidence is an evidence that supports service marketing. Research results show that physical evidence a restaurant influences the frequency of consumer's visit to the restaurant (Table 9). According to Felix (2013) interior of a restaurant needs a typical characteristic or design. This characteristic will later on create an atmosphere that gives the consumers their own experience. According to Ma'ruf in Andreani et al. (2013) differentiation and innovative marketing efforts can be used to improve competitive superiority. One of the innovative marketing efforts is creativity in making a unique restaurant's atmosphere. Respondents themselves like natural interior for a restaurant of fruit ice beverage-base, which is also completed with supporting facilities, such as toilet, parking lot, and wifi/internet (Table 10 and Table 11). Nevertheless, the more complete the facilities are in one service business, the more consumers will come.

Another marketing mix element is people or participant, that is any aspects that are related to a personnel expertise that is involved in the business. In a restaurant business, employees that provide the service directly or indirectly to the consumers are participants that belong to this element. Table 12 presents information that employees; knowledge about products they sell is very important. Therefore, it is important to conduct a good and appropriate training for employees, especially those that directly deal with the customers. Furthermore, respondents say that wearing uniform is also necessary for the employees.

The last marketing mix element is process. Process is an activity that shows how service is delivered to consumers. In this case, process in a restaurant is related to the service given during the process of purchasing foods and beverages. A service element is closely related to the participant element. Table 13 shows that majority of respondents say that a restaurant service affects the frequency of customers' visit. Furthermore, respondents are interested in facilities of making their own fruit combination in a fruit-beverage-based restaurant. In this case, respondents have a freedom to choose the fruit that they are going to eat based on their preference. Therefore, it is important to have a system that is well integrated to support the service process and to implement an innovation to be developed later.

\section{Factors Affecting the Desire to Purchase Fruit beverages}

In this analysis, respondents of fruit beverages are classified into two groups, namely those who want to buy fruit beverages and those who don't. Both groups are dependent variables. The independent variables are marketing mix elements, namely product, price, place, promotion, physical evidence, process and people.

Independent variables that distinguish consumer behavior are those that have Sig. value $<0,05$. Based on the results of the discriminant analysis presented in Table 14, it shows that price element has a Sig. value $<0,05$, that is 0,07 and physical evidence has Sig. value 0,048 . This means that there is a difference between the group that wants to buy fruit beverages and the one that does not, which is influenced by price element and physical evidence element. It can also be said that respondents that buy fruit beverages and those that don't are affected by their behavior towards the price of fruit beverages and the physical evidence of the restaurant. The results of analysis show that price has more influence on the customer's decision making than physical evidence.

The analysis also shows that there are some determining factors of discriminant function that are presented in Table 15, where the discriminant function formed is as follows:

$\mathrm{D}=-3,339+0,619$ Physical $+0,899$ Price

The function is to find out consumers that are divided into two groups, namely those who buy fruit beverages and those who don't, each of which can only be put into one group. However, the function cannot determine whether the consumers belong to the group of those who buy fruit beverages or not. Therefore, the function must be followed up with calculating the limit value (cut-off). Calculation to get a limit value in order to distinguish both groups is by using the following formula: 


$$
\operatorname{Cut}_{\text {off }}=\frac{\mu_{1} n_{0}+\mu_{0} n_{1}}{n_{1}+n_{0}}
$$

Notes:

$\mu_{0}$ : group centroid for group 0 (those who buy fruit beverages)

$\mu_{1}$ : group centroid for group1 (those who don't buy fruit beverages)

$\mathrm{n}_{0}$ : number of consumers that buy fruit beverages, namely 64 consumers

Table 9. Perception of physical evidence element

\begin{tabular}{|c|c|c|c|c|c|}
\hline \multirow{2}{*}{ Statements } & \multicolumn{5}{|c|}{ Percentage $(\%) ; n=100$} \\
\hline & SS & $\mathrm{S}$ & $\mathrm{N}$ & TS & STS \\
\hline Interior of a restaurant affects the frequency of your visit & 16 & 45 & 32 & 7 & - \\
\hline
\end{tabular}

Table 10. Concept of a restaurant's interior that is based on fruit beverages

\begin{tabular}{lc}
\hline \multicolumn{1}{c}{ Restaurant interior suitable with a restaurant ior restoran that is based on fruit beverages } & Percentage $(\mathrm{n}=100)$ \\
\hline Ethnic/traditional & $12 \%$ \\
Modern & $7 \%$ \\
Natural & $37 \%$ \\
Minimalist & $28 \%$ \\
Fruit-concept & $15 \%$ \\
Others & $1 \%$ \\
\hline
\end{tabular}

Table 11. Facilities desired by consumers

\begin{tabular}{lcc}
\hline \multicolumn{1}{c}{ Facilities desired } & Number of respondents & Percentage $(\%)$ \\
\hline Toilet & 71 & 21.90 \\
Parking lot & 60 & 22.26 \\
Wifi/internet & 61 & 12.4 \\
Payment by credit (debit/credit) & 34 & 14.23 \\
Delivery service & 39 & 2.92 \\
Others & 8 & 26.27 \\
\hline
\end{tabular}

Table 12. Perception of participant element

\begin{tabular}{|c|c|c|c|c|c|}
\hline \multirow{2}{*}{ Statements } & \multicolumn{5}{|c|}{ Percentage $(\%) ; \mathrm{n}=100$} \\
\hline & $\mathrm{SS}$ & $\mathrm{S}$ & $\mathrm{N}$ & $\mathrm{TS}$ & STS \\
\hline $\begin{array}{l}\text { Employees' knowledge about products they sell in a fruit-beverage-based restaurant is } \\
\text { very important }\end{array}$ & 25 & 56 & 12 & 7 & - \\
\hline $\begin{array}{l}\text { Wearing uniform is very important for employees working in a fruit-beverage-based } \\
\text { restaurant. }\end{array}$ & 15 & 36 & 36 & 13 & - \\
\hline
\end{tabular}

Table 13. Perception of process element

\begin{tabular}{|c|c|c|c|c|c|}
\hline \multirow{2}{*}{ Statements } & \multicolumn{5}{|c|}{ Percentage $(\%) ; n=100$} \\
\hline & SS & $\mathrm{S}$ & $\mathrm{N}$ & TS & STS \\
\hline Service in a restaurant influences the frequency of your visit. & 19 & 45 & 24 & 12 & - \\
\hline $\begin{array}{l}\text { You will be interested in the facilities of 'choosing your own fruit ice combination' in a } \\
\text { fruit-beverage-based restaurant. }\end{array}$ & 37 & 42 & 17 & 4 & - \\
\hline
\end{tabular}


Table 14. Test results of independent variables

\begin{tabular}{lccccc}
\hline \multicolumn{1}{c}{ Variable } & Wilks' Lambda & F & df1 & df2 & Sig. \\
\hline Product & 1,000 & 0,044 & 1 & 98 & 0,835 \\
Price & 0,927 & 7,697 & 1 & 98 & 0,007 \\
Place & 0,973 & 2,696 & 1 & 98 & 0,104 \\
Promotion & 0,998 & 0,176 & 1 & 98 & 0,676 \\
Physical & 0,961 & 4,021 & 1 & 98 & 0,048 \\
Process & 0,997 & 0,326 & 1 & 98 & 0,569 \\
People & 0,985 & 1,505 & 1 & 98 & 0,223 \\
\hline
\end{tabular}

Table 15. The framer of discriminant function

\begin{tabular}{lcc}
\hline & Variable & Function 1 \\
\hline Physical & 0,619 \\
Price & 0,899 \\
(Constant) & $-3,339$ \\
\hline
\end{tabular}

From the results of discriminant test, we can get output classification results in which the original grouped cases correctly classified value gets as much as $60 \%$, which means that as much as $60 \%$ data has been classified well. Furthermore, the results of cross-validated grouped cases correctly classified that function to reduce bias in the previous classification process show as much as $60 \%$ or the same as the previous results. Both results are more than $50 \%$, which means that the model or function of discriminant has been formed is feasible to distinguish both consumer groups, namely those that want to buy fruit beverages and those who don't.

Based on the results of discriminant analysis it is found out that price and physical evidence factors affect the desire to purchase fruit beverages. In this case consumers of fruit beverages make a consideration of buying that is affected by product price and its physical evidence of the fruit-beverage-based restaurants in Bogor City. The earlier researches show that there is a similarity about price factor that affects buying, namely Senjaya (2014) on Japanese food in Hayashi Teppan, Aritonang (2014) on cattle feed (soybean oilcake), and Susanti (2003) on toothpaste 'pepsodent'. Physical evidence factor is known to influence life insurance purchase in the research carried out by Marwa (2014).

\section{Strategic Implications of Marketing Fruit beverages in Fruit Ice beverage-based Restaurants}

Based on the research results carried out, it is found out that price and physical evidence factors influence the customers' desire to buy fruit beverages in Bogor City. Consumers want the price of fruit beverages as they expect. In this research consumers consider a reasonable price for fruit beverages is between Rp10.000 and Rp15.000. Nevertheless, determining the price must consider the costs that must be borne in the production process from the upstream to downstream. Choosing the fruits that will be used is also important. Fruits that are easily produced and obtained will have lower price, compared to those that are difficult to produce and get. Therefore, it is necessary to have a good cooperation with local fruit farmers surrounding Bogor area. This can reduce production cost so that it is expected that producers of fruit beverages can set the price as the consumers expect.

A marketing mix element that also affects the desire to buy fruit beverages is physical evidence. A physical evidence of a restaurant includes the building, interior design, equipment and facilities of the restaurant. Physical evidence of a restaurant gives the consumers comfort. Furthermore, a restaurant that gives something special in its concept will leave a different impression to the consumers. That will affect the consumers' intention to buy fruit beverages in Bogor City. The research results show that consumers of fruit beverages like a minimalist natural interior concept in a fruitbeverage-based restaurant. Besides, consumers expect there are complete facilities, in which the priorities are toilet, parking lot, and internet (wifi).

Other marketing mix elements, although they do not influence the customers' desire to purchase fruit beverages, the information that we get can be used as a supporting material for the marketing strategies of a fruit-beverage-based restaurant. The implications of marketing strategies are presented in Table 16. 
Table 16. Implications of marketing strategies based on marketing mix elements

\begin{tabular}{lll}
\hline Attributes & & Managerial implications \\
\hline Product & $\rightarrow$ & Creating new combinations of fruits based on the consumers' preference \\
& $\rightarrow$ & Creating innovation by choosing their own fruit combinations and preparing information on the nutrient \\
& content of the fruits they choose \\
Place & $\rightarrow$ Choosing locations of restaurants by considering their surrounding that has similar activities, such as \\
Promotion & $\rightarrow$ & Developing promotion through social media \\
People & $\rightarrow$ & Supporting training carried out well and appropriately by evaluating continuously all the employees so \\
& & that their service quality can always be maintained
\end{tabular}

\section{CONCLUSIONS AND RECOMMENDATIONS}

\section{Conclusions}

Conclusion of the research results show that price and physical evidence factors influence consumers to buy fruit beverages. The marketing strategies of fruit beverages must pay attention to the consumers' consideration on the product price and the restaurant's physical evidence. Other marketing mix elements do not influence the consumers' desire to buy fruit beverages; however, information that we can get can be used to support the marketing strategies of the product. One of them is innovation development that is preferred by the consumers is choosing their fruit combinations for their fruit beverages. This innovation is recommended to be supported with social media development as its promotion media.

\section{Recommendations}

Fruit beverages are a type of drink that has long been known by Indonesian people. Nevertheless, some business development by adding value to fruit ice beverage products has got good responses from the people in Bogor City, and this business has developed well as an innovative business. From the research that has been carried out, it is suggested that the restaurant owners of fruit beverages in Bogor City should pay attention to price and physical evidence factors because both of them influence the customers' desire to buy the product. The managerial implications based on the research results can also be used as additional marketing strategies in developing business in fruit beverage-based restaurants.

\section{REFERENCES}

Andreani F, Kristanti M, Yapola A. 2013. Pengaruh store layout, interior display, human variable terhadap customer shopping orientation di restoran dewandaru surabaya. JMK. 15(1): 6574. http://dx.doi.org/10.9744/jmk.15.1.65-74.

Aritonang PA. 2014. Analisis pengaruh bauran pemasaran terhadap keputusan pembelian bahan baku bungkil kedelai pada industri pakan ternak di Indonesia [tesis]. Bogor: Institut Pertanian Bogor.

Dudesy RP. 2014. Analisis kepuasan konsumen dan sensitivitas harga di Sop Duren Lodaya Coffee and Resto [skripsi]. Bogor: Institut Pertanian Bogor.

Felix T, Santosa A, Utami HS. 2013. Perancangan interior restoran dengan pendekatan ekologis di Surabaya. J Intra 1(1): 1-8.

Garcia-Alonso M, Pascual-Teresa S, Santos-Buelga C, Rivas-Gonzalo JC. 2004. Evaluation of the antioxidant properties of fruits. Food Chemistry. 84: 13-18. http://dx.doi.org/10.1016/S03088146(03)00160-2

Ginting SU. 2011. Pola makanan dan minuman menuju budaya hidup sehat. Jurnal Ilmu Keolahragaan 9(2): 52-66.

Indrajaya B. 2006. Analisis preferensi konsumen terhadap restoran penyaji makanan hasil laut (Studi kasus pada Restoran Seafood Rasane) [tesis]. Bogor: Institut Pertanian Bogor.

[Kompas] Kompas.com. 2014. Bima Arya berharap PHRI motor pariwisata Kota Bogor.http://travel. kompas.com/read/2014/02/22/1335253/Bima. Arya.Berharap.PHRI.Motor.Pariwisata.Kota. Bogor.[8 Juni 2015].

Kotler P. 2003. Marketing Management. New Jersey: Prentice Hall International. 12nd Ed. 
Lin SM. 2011. Marketing Mix (7P) and Performance Assesment of Western Fast Food Industry in Taiwan: An Application by Associating DEMATEL and ANP. African Journal of Business Management 5(25): 10634-10644.

Marwa S. 2014. Pengaruh bauran pemasaran jasa terhadap keputusan pembelian asuransi jiwa individu di Kota Bogor [tesis]. Bogor: Institut Pertanian Bogor.

Mowen JC, M Minor. 1999. Consumer Behaviour. New Jersey : Prentice Hall.

Nainggolan O, Adimunca C. 2005. Diet Sehat Dengan Serat. Cermin Dunia Kedokteran No. 147. Jakarta: Departemen Kesehatan RI.

Pardede E. 2013. Tinjauan komposisi kimia buah dan sayur: Peranan sebagai nutrisi dan kaitannya dengan teknologi pengawetan dan pengolahan. J. VISI. 21 (3): 1-16.

Piironen V, Toivo J, Puupponen-Pimia R, Lampi A. 2003. Plant terols in vegetables, fruits and berries. J. Sci. Food Agric. 83: 330-337. http:// dx.doi.org/10.1002/jsfa.1316

Rachmawati R. 2011. Peranan bauran pemasaran (marketing mix) terhadap peningkatan penjualan (sebuah kajian terhadap bisnis restoran). Jurnal Kompetensi Teknik 2(2): 143-150.

Ria R. 2014. Analisis faktor-faktor yang memengaruhi preferensi konsumen terhadap buah lokal [tesis]. Bogor: Institut Pertanian Bogor.

Rochani HTTD. 2007. Analisis Preferensi Konsumen Terhadap Atribut Sop Buah Pak Ewok (Kasus di Bogor, Jawa Barat) [skripsi]. Bogor: Institut Pertanian Bogor.
Santoso A. 2011. Serat pangan (Dietary Fiber) dan manfaatnya bagi kesehatan. Magistra 75(23): $35-40$

Schiffman GL, Kanuk LL. 2000. Perilaku Konsumen. Jakarta: Indeks.

Senjaya HG. 2014. Pengaruh Bauran Pemasaran Terhadap Keputusan Pembelian Masakan Jepang di Hayashi Teppan (Survey Terhadap Konsumen Hayashi Teppan di Food Court BEC). E-Journal Graduate Unpar 1(2): 199-210.

Siswanto T. 2013. Optomalisasi sosial media sebagai media pemasaran usaha kecil menengah. Jurnal Liquidity 2(1): 80-86.

Sumarwan U. 2011. Perilaku Konsumen, Teori dan Penerapannya dalam Pemasaran. Jakarta: Penerbit Ghalia Indonesia.

Susanti. 2013. Analisis faktor bauran pemasaran yang memengaruhi keputusan konsumen dalam melakukan pembelian pasta gigi pepsodent (Studi Kasus di Wilayah Cengkareng). Jurnal Akuntansi dan Manajemen Esa Unggul 1(1): 143-149.

Terry P, Terry JB, Wolk A. 2001. Fruit and vegetable consumption in the prevention of cancer: an update. Journal Internal Medicine. 250: 280-290. http://dx.doi.org/10.1046/j.13652796.2001.00886.x

Widowati M. 2010. Pengaruh Harga, Promosi dan Merek Terhadap Penjualan Barang Pharmasi di PT. Anugrah Pharmindo Lestari. Fokus Ekonomi 5(1): 55-69.

[Wikipedia] Wikipedia. 2014. Es Teler 77. http:// id.wikipedia.org/wiki/Es_Teler_77.[5Juni 2015]. 